\title{
Glucose, insulin and cholesterol levels in blood of growing pigs given diets with various sources of fibre*
}

\author{
A. Antuszewicz, E. Święch ${ }^{1}$ and T. Żebrowska \\ The Kielanowski Institute of Animal Physiology and Nutrition, Polish Academy of Sciences \\ 05-110 Jabtonna, Poland
}

\begin{abstract}
The effect of feeding diets containing $10 \%$ of either cellulose, or apple pulp, pectin, sugar beet pulp, or potato pulp, on preprandial and postprandial changes of plasma concentration of glucose and insulin, and on the cholesterol level $8 \mathrm{~h}$ after the meal, were determined in pigs of $39 \mathrm{~kg}$ body weight. Glucose and cholesterol concentrations were not affected by the type of fibre. The insulin concentration shortly after the meal was the highest in pigs fed on potato pulp and the lowest on cellulose, while 45 and 60 min postprandially, it was higher on pectin than on other fibre sources.
\end{abstract}

KEY WORDS: dietary fibre, plasma, glucose, insulin, cholesterol, pigs

\section{INTRODUCTION}

Dietary fibres alter the process of digestion and absorption of nutrients, lower plasma cholesterol and affect plasma insulin concentrations. Soluble dietary fibre, such as guar gum, significantly decreased glucose absorption in the small intestine of pigs (Rainbird et al., 1984), markedly reduced the peak postprandial plasma glucose and insulin concentrations (Heppell, 1985; Sambrook and Rainbird, 1985), and lowered the plasma cholesterol level in rats (Overton et al., 1994). On the other hand, in pigs fed diets with sugar beet fibre and wheat bran, no effect on glucose concentration in portal and arterial blood was observed (Michel and Rerat, 1998).

The aim of the presented study was to determine whether dietary fibre from food industry by-products added to diets influences the level of glucose, insulin and cholesterol in the blood of growing pigs.

\footnotetext{
* Supported by V Framework Programme (CRAFT-Profibre) and The State Committee for

Scientific Research, Grant No. 2PO6Z05727

${ }^{1}$ Corresponding author: e-mail: e.swiech@ifzz.pan.pl
} 


\section{MATERIAL AND METHODS}

Twelve male pigs of approximately $39 \mathrm{~kg}$ liveweight were fitted with an indwelling catheter inserted into the jugular vein for blood sampling, and were fed on five diets with different fibre sources. The control diet contained $10 \%$ cellulose, and each of the four diets contained $10 \%$ of dry fibre products: apple pulp, apple pectin, sugar beet pulp, or potato pulp. The diets were tested in a cross-over design ( 6 pigs per diet). The diets $(1.8 \mathrm{~kg} /$ day $)$ were offered twice daily in equal meals at 08.00 and $20.00 \mathrm{~h}$; feed was mixed with water at a 1:1 ratio; water was available all of the time. After 4 days of adaptation to the diet, blood samples were taken at the following times: before the morning feeding at 8.00 and after feeding at 8.15, 8.30, 8.45, 9.00, 9.30, 10.00, 10.30, $11.00,12.00,13.00,14.00$ and $16.00 \mathrm{~h}$. Seven $\mathrm{ml}$ samples of blood were withdrawn, transferred to heparinized tubes and immediately centrifuged. Samples of plasma $(1.5 \mathrm{ml})$ were stored at $-20^{\circ} \mathrm{C}$ until analysis. Plasma glucose and plasma cholesterol were measured using a biochemical diagnostic analyser (Vitros DTII). Insulin was measured by RIA using Insulin RIA kits (POLATOM, Poland). The total cholesterol level in blood was measured in samples taken at $8 \mathrm{~h}$ after the meal. Statistical analysis of results was performed using SPSS ver. 11.5.

\section{RESULTS AND DISCUSSION}

The chemical analysis of the fibre products shows that soluble fibre contents in the potato, sugar beet and apple pulp were similar (15-18\% DM), but the insoluble fibre was the highest in sugar beet pulp (64\% of DM). The potato pulp contained about $30 \%$ starch in DM.

Pigs consumed the entire portion of feed given in about $10 \mathrm{~min}$, but the diet containing pectins was eaten in about 15 to $20 \mathrm{~min}$.

The mean plasma glucose concentration patterns over $8 \mathrm{~h}$ for all diets are shown in Figure 1. The type of fibre products did not affect the plasma glucose values before the meal, what was expected, since the major action of dietary fibre on glucose absorption takes place after feeding. The mean postprandial plasma glucose concentration increased shortly after feeding potato and apple pulp diets, which might be explained in part by the fact that these products contain some sugars. In the period from $45 \mathrm{~min}$ to $8 \mathrm{~h}$ after feeding the concentration of plasma glucose was low and similar for all the diets. The smallest changes in plasma glucose concentrations were when pigs were fed pectin diets. Although there were some indications of an effect of fibre source on plasma glucose concentrations, the differences were not statistically significant, perhaps because of the large individual variation. Based on other studies (Rainbird et al., 1984; Sambrook et al., 1985), 


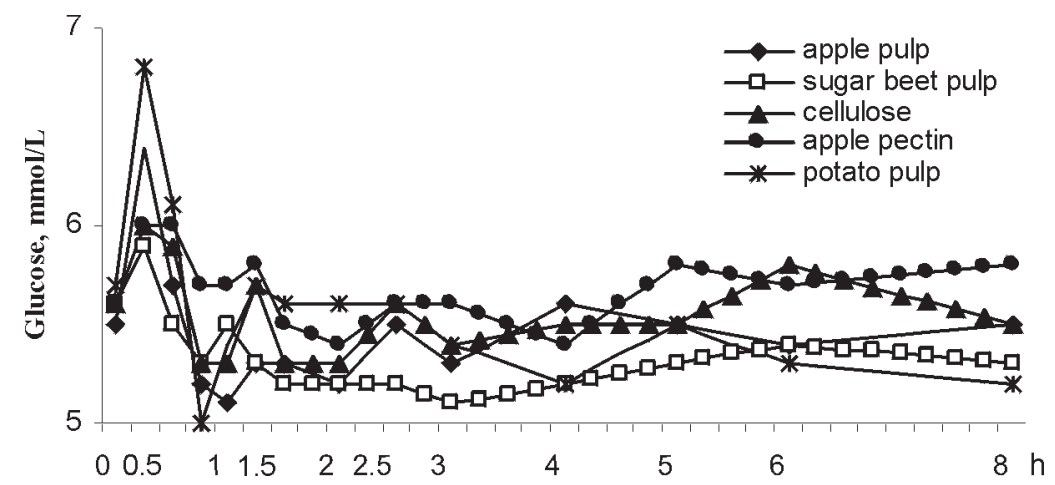

Figure 1. Profile of plasma glucose concentration

it can be explained that pectin, as a soluble fibre, slows down the postrandial rise in blood glucose by two different mechanisms: by altering viscosity, thus delaying gastric emptying and intestinal absorption, and by inducing changes in the intestinal barrier layer. Still, the plasma glucose level after feeding the sugar beet pulp diet was also low. Sugar beet fibre is only partly soluble, and it is unlikely that this soluble fibre fraction induces a sufficient increase in the viscosity of digesta to delay starch digestion or absorption.

The preprandial plasma insulin values were low and ranged from 9 to 14 $\mathrm{U} / \mathrm{ml}$ for sugar beet pulp and pectin diets, respectively (Figure 2). The fifteen min postprandial plasma insulin level was the highest after the potato pulp diet and the lowest for the cellulose $\operatorname{diet}(\mathrm{P}<0.01)$. The plasma insulin concentration value 45 min after feeding was markedly greater for the pectin $(\mathrm{P}<0.05)$ than for the other diets, and at $60 \mathrm{~min}$ the highest insulin concentration was for the pectin and the lowest for the cellulose diet $(\mathrm{P}<0.01)$. The plasma insulin

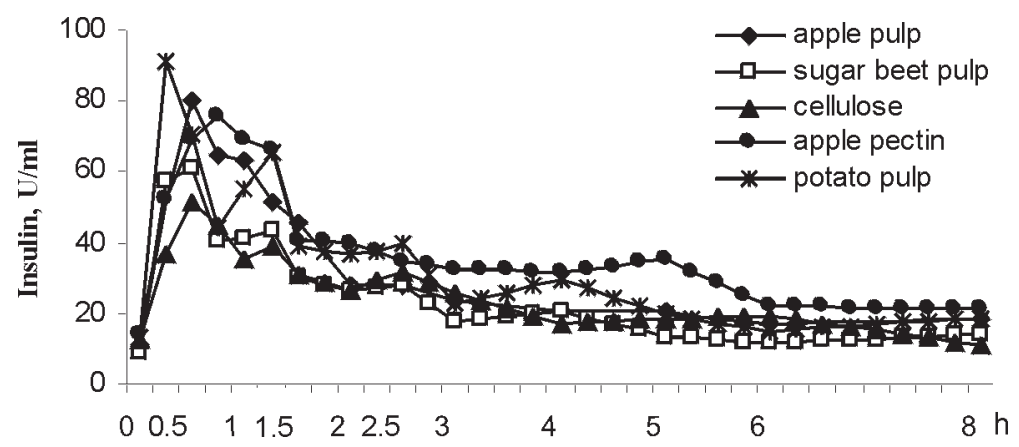

Figure 2. Profile of plasma insulin concentration 
concentrations subsequently declined, and $8 \mathrm{~h}$ after feeding ranged from 11 (cellulose diet) to $21 \mathrm{U} / \mathrm{ml}$ (pectin diet). These results correspond with changes of glucose concentrations in blood plasma.

The values of total cholesterol concentrations in plasma ranged only from 2.1 to $2.3 \mathrm{mmol} / \mathrm{L}$ in pigs given all diets.

In conclusion, by-products containing dietary fibre had no significant effect on preprandial or postprandial plasma glucose and cholesterol concentrations, but significantly influenced plasma insulin concentrations during the first $60 \mathrm{~min}$ after the meal.

\section{REFERENCES}

Heppell L.M.J., Rainbird A.L., 1985. Effect of the physical form of dietary guar gum on nutrient absorption in the pig. Proceedings of 3rd International Seminar on Digestive Physiology in the Pig. 580 Beretning fra Statens Husdyrbrugsforsøg, pp.58-60

Michel P., Rerat A., 1998. Effect of adding sugar beet fibre and wheat bran to starch diet on the absorption kinetics of glucose, amino-nitrogen and volatile fatty acids in the pig. Reprod. Nutr. Develop. 38, 49-68

Rainbird A., Low A.G., Żebrowska T., 1984. Effect of guar gum on glucose and water absorption from isolated loops of jejunum in conscious growing pigs. Brit. J. Nutr. 52, 489-498

Overton P.D., Furlonger N., Beety J.M., Chakkaborty J., Tredger J.A., Morgan L.M., 1994. The effects of dietary sugar-beet fibre and guar gum on lipid metabolism in Wistar rats. Brit. J. Nutr. $72,385-395$

Sambrook I.E., Rainbird A.L., 1985. The effect of guar gum and level and source of dietary fat on glucose tolerance in growing pigs. Brit. J. Nutr. 54, 27-35

\section{STRESZCZENIE}

Poziom glukozy, insuliny i cholesterolu w krwi świń żywionych dietami zawierającymi różne rodzaje włókna

Na świniach o m.c. $39 \mathrm{~kg}$ badano wpływ skarmiania diet zawierających $10 \%$ celulozy lub wytłoków jabłecznych, pektyny jabłkowej, wysłodków buraczanych bądź pulpy ziemniaczanej, na zmiany koncentracji glukozy i insuliny przed karmieniem i w 8 godzin po karmieniu, oraz poziom cholesterolu w 8 godzin po posiłku. Rodzaj włókna w diecie nie miał wpływu na stężenie glukozy i cholesterolu w osoczu. Stężenie insuliny w krwi bezpośrednio po posiłku było największe u świń żywionych dietą z pulpą ziemniaczaną, a najmniejsze - dietą z celulozą, natomiast w 45 i 60 min po karmieniu u zwierząt żywionych dietą z pektyną. 